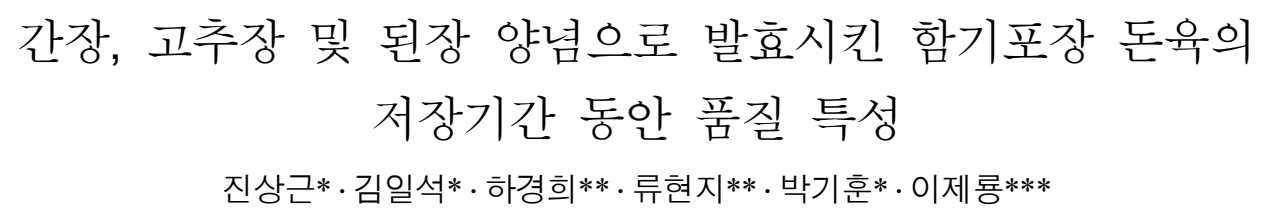

진주산업대학교 동물소재공학과*, 농촌진흥청 축산연구소**, 경상남도 첨단양돈연구소***

\title{
Quality Characteristics of Aerobic Packed Pork during Storage after Fermentation with Soy Sauce, Red Pepper and Soybean Paste Seasonings
}

\author{
S. K. Jin*, I. S. Kim*, K. H. Hah**, H. J. Lyou**, K. H. Park* and J. R. Lee*** \\ Department of Animal Resources Technology, Jinju National University*, \\ National Livestock Research Institute**, \\ Advanced Swine Research Institute, Gyeongnam Province***
}

\begin{abstract}
This study was carried out to evaluate the quality characteristics of aerobic packed pork during storage after fermentation with soy sauce, red pepper and soybean paste seasonings. The ham of pork were cut to cube $(7 \times 10 \times 2 \mathrm{~cm})$ and Korea traditional seasonings such as soy sauce(T1), red pepper paste(T2), soybean paste(T3) were seasoned by the proportions of meat to seasonings(1:1), respectively. The seasoned sample were fermented by fill into plastic box at $1 \pm 1^{\circ} \mathrm{C}$ for 10 days. And then, the fermented meat from each pack was aerobic packed and stored at $1 \pm 1{ }^{\circ} \mathrm{C}$ for up to 28 days. The $\mathrm{pH}$ of $\mathrm{T} 1$ were significantly $(\mathrm{P}<$ $0.05)$ lower compared to $\mathrm{T} 2$ and $\mathrm{T} 3$ at 1 day of storage, but were significantly $(\mathrm{P}<0.05)$ higher at 14 and 28 days of storage. The water-holding capacity of $\mathrm{T} 1$ were significantly $(\mathrm{P}<0.05)$ higher compared to $\mathrm{T} 2$ and $\mathrm{T} 3$ at 1 and 28 days of storage. The shear force of $\mathrm{T} 3$ were significantly $(\mathrm{P}<0.05)$ lower compared to $\mathrm{T} 1$ during storage. The surface meat $\mathrm{L}^{*}$ values of $\mathrm{T} 3$ were significantly $(\mathrm{P}<0.05)$ higher than those of $\mathrm{T} 1$ and $\mathrm{T} 2$, but $\mathrm{a}^{*}$ and $\mathrm{b}^{*}$ values of $\mathrm{T} 2$ were significantly $(\mathrm{P}<0.05)$ higher. The volatile basic nitrogen $(\mathrm{VBN})$ of $\mathrm{T} 3$ were significantly $(\mathrm{P}<0.05)$ lower compared to $\mathrm{T} 2$ at 1 and 14 days of storage, but $\mathrm{T} 1$ were significantly $(\mathrm{P}<0.05)$ lower at 28 days of storage. The thiobarbituric acid reactive substances(TBARS) of T3 were significantly $(\mathrm{P}<0.05)$ lower compared to $\mathrm{T} 1$ and $\mathrm{T} 2$. The total plate counts of $\mathrm{T} 1$ were significantly $(\mathrm{P}<0.05)$ lower compared to $\mathrm{T} 2$ and $\mathrm{T} 3$ at 1 day of storage, but $\mathrm{T} 2$ were significantly $(\mathrm{P}<$ $0.05)$ lower at 14 and 28 days of storage. The Escherichia coli of $\mathrm{T} 1$ and $\mathrm{T} 3$ were significantly $(\mathrm{P}<0.05)$ lower compared to T2 at 1 day of storage. The Lactobacilli spp. of $\mathrm{T} 2$ were significantly $(\mathrm{P}<0.05)$ lower compared to $\mathrm{T} 1$ and $\mathrm{T} 3$.
\end{abstract}

(Key words : Aerobic package, Korea traditional seasonings, Fermented pork)

Corresponding author : I. S. Kim, Department of Animal Resources Technology, Jinju National University, Jinju, 660-758, Korea. Tel : 82-55-751-3288, Fax : 82-55-758-1892, E-mail : iskim@jinju.ac.kr 


\section{I. 서 론}

21세기는 건강지향적인 “기능성 식품시대"로 서 식품의 기능성과 위생성을 강조하는 식품들 이 소비자들로부터 호응도가 높아지고 있으며, 동물성 단백질과 지방의 과다섭취에 따른 성인 병 및 기타 질병 발생의 문제점을 부분적으로 해소할 수 있는 돼지의 가공저장법이 요구되 고 있다.

축육 식품 가운데 돼지고기는 쇠고기에 비해 값이 저렴하고 영양 면에서도 손색이 없어 대 중들로부터 널리 애용되는 육류이다(최와 이, 2002). 1인당 돼지고기 소비량은 90 년도에 11.8 $\mathrm{kg}$ 에서 99 년도에는 $16.1 \mathrm{~kg}, 2000$ 년도에는 16.5 $\mathrm{kg}$ 으로 증가하였고, 이러한 증가 추세는 앞으 로도 계속될 전망이다(MAF, 2001). 돼지고기 소비가 증가하면서 전통적인 돼지고기 가공품 인 양념육의 시장규모 또한 급속히 성장하고 있다. 국내 관계 법규에 따른 양념육의 정의를 살펴보면, ‘식육에 식염, 조미료, 향신료 등으로 양념하고 냉장 또는 냉동한 것으로 육 함량 $60 \%$ 이상의 것을 말한다(KFDA, 2002)로 되어 있다. 또한 양념육에 적용되는 성분의 규격은 성상으로 고유의 색택을 가지고 이미, 이취가 없고, 아질산이온은 $70 \mathrm{ppm}$ 이하이며 보존료로 서 소르빈산과 소르빈산 칼륨이 $2 \mathrm{~g} / \mathrm{kg}$ 이하여 야 한다고 규정되어 있다(KFDA, 2002). 양념육 에 사용되는 양념류는 통상 육취의 제거뿐만 아니라 연육작용으로 소화흡수를 도와준다 (Moon 등, 1991).

발효육은 자가 숙성에 의하여 이루어지며 이 에 의하여 발생되는 근육의 변화로는 근육단백 질에 있어서 폴리펩타이드 체인의 응고에 의한 근섬유 단백질의 용해성 감소(Crepo 등, 1978) 와 체인의 일부가 절단되면서 연해짐은 물론 유리아미노산, 핵산 및 관련물질, 아민류, 암모 니아, 크레아틴 등 비단백태 질소화합물이 증
가하여 제품은 독특한 맛과 향을 내게 되며 (Dierick 등, 1974), 또한 지방도 분해되어 키톤 알데하이드, 알콜올류로 변하여 방향성 증진에 기여하게 된다(Whitaker, 1978).

식육의 포장은 육의 품질 저하를 최소화하고 장기간 보존하기 위하여 실시하는 것으로 오래 전부터 식육을 저장하고 포장하는 기술들이 개 발되어 왔다. 식육은 $70 \%$ 의 물과 대사산물, 아 미노산, 펩타이드, 뉴클레오타이드와 당분 등으 로 인하여 미생물의 성장이 빠르게 이루어지고 (Lawrie, 1985), 포장과 저장방법에 따라 육질의 변이가 다르게 나타난다. 식육을 장기 저장하 는데 영향을 미치는 요인으로는 염장, 발효, 건 조, 보존료 첨가, 냉장 및 냉동, 포장방법(Gill와 Badoni, 2002) 등 여러 가지가 있다. 우리 조상 들은 함기포장을 하면서 저장기간을 연장할 수 있는 한 방법으로 식염의 방부작용에 의한 염 장법이나 발효기술을 이용해 왔으며, 한국인들 은 거의 모든 식품에서 간장, 고추장 및 된장 을 주로 이용하고 있고, 이들은 독특한 향과 맛을 지닌 전통적인 조미료로써 우리 입맛에 매우 친숙한 재료이다.

양념육은 아직까지 양념재료나 제조법이 체 계화 되어 있지 않으며 가정이나 일부 음식점 에서만 조리·판매되고 있을 뿐만 아니라 유통 기한의 설정과 이의 연장을 위한 기술적 체계 가 제대로 확립되어 있지 않아 저장과 유통 과 정 중 많은 문제점들이 나타나고 있다(최와 이, 2002). 특히, 양념육을 발효 숙성 시킨 후 포장 하여 제품화한 경우는 우리나라에서 많지 않은 실정이다.

따라서 본 연구는 간장, 고추장 및 된장 양 념과 돼지 뒷다리 부위를 이용해 전통 발효 돈 육을 개발한 후 함기포장하여 저장기간 동안 발효 돈육의 품질특성에 미치는 영향에 대해 알아보고자 하였다. 


\section{II. 재료 및 방법}

1. 공시재료 및 양념 배합비

돼지를 도축 후 24시간 냉각된 지육 중에서 농림부가 고시한 “식육의 부위별·등급별 및 종류별 구분방법(농림부 고시 제2004-67호)”에 준하여 돼지 뒷다리 부위를 분할·골발·정형 하였다. 준비한 시료들을 $7 \times 10 \times 2 \mathrm{~cm}$ 크기로 자른 후 Table 1 과 같은 배합비의 양념액 반죽 에 각각 침지(양념페이스트 1 : 뒷다리 부위육 1)시켜 $1 \pm 1{ }^{\circ} \mathrm{C}$ 에서 10 일간 숙성한 후 Nylon (PA) 3 방에 넣어 함기 상태로 실링 포장하였다. 포장 후 $1 \pm 1^{\circ} \mathrm{C}$ 에 저장하면서 1,14 및 28 일에 품질 측정에 이용하였다.

Table 1. Formula of Korean traditional seasoned sauce containing soy sauce, red pepper and soybean paste

(Unit : \%)

\begin{tabular}{lrcr}
\hline \multirow{2}{*}{ Ingredients } & \multicolumn{3}{c}{ Treatments $^{1)}$} \\
\cline { 2 - 4 } & T1 & T2 & T3 \\
\hline \hline Soy sauce & 22 & & \\
Red pepper paste & & 43 & 30 \\
Raw soybean paste & & & 10 \\
Ground onion & 10 & & 9 \\
Ground radish & 5 & & 8 \\
Ground garlic & 7 & 6 & 2 \\
Ground ginger & 2 & & 23 \\
Corn syrup & 32 & 23 & 18 \\
Water & 22 & 28 & 100 \\
\hline Total & 100 & 100 & \\
\hline 1) T1 : Soy sauce base, T2 : Red pepper paste base, \\
T3 : Soybean paste base.
\end{tabular}

\section{2. 분석방법}

(1) $\mathrm{pH}$

육은 근막, 지방 등을 제거한 후 세절하여
$10 \mathrm{~g}$ 을 증류수 $90 \mathrm{ml}$ 와 함께 homogenizer(IKA, T25 Basic Malaysia)로 13,500 rpm에서 10초간 균질하여 $\mathrm{pH}-\mathrm{meter}(\mathrm{Orion} 230 \mathrm{~A}$, USA)로 측정하 였다.

(2) 보수력

마쇄한 시료를 $70^{\circ} \mathrm{C}$ 의 항온수조에서 30 분간 가열한 다음 냉각하여 $1,000 \mathrm{rpm}$ 에서 10 분간 원 심분리한 후 무게를 측정하였다.

보수력 $(\%)=\frac{(\text { 총 시료 중량 }- \text { 유리수분 중량 })}{\text { 총 시료 중량 }} \times 100$

(3) 전단가

Instron(Model 3343, England)을 이용하여 가 열육에 대해 전단가(Warner-Bratzler shear value) 를 검사하였으며, $50 \mathrm{~kg}$ load cell을 이용하였고, chart speed와 crosshead의 speed는 각각 200 $\mathrm{mm} / \mathrm{min}$ 이었다.

\section{(4) 육색}

표면육색은 고기의 표면에 묻어 있는 양념은 증류수로 한 번 씻은 후 물기를 제거한 다음 Chromameter(Minolta Co. CR 301, Japan)를 이용 하여 동일한 방법으로 5 회 반복하여 측정하였 으며, 심부 육색은 고기를 절단한 다음 그 단 면을 표면 육색과 동일한 방법으로 측정하여 명도(lightness)를 나타내는 L*값, 적색도(redness) 를 나타내는 $\mathrm{a}^{*}$ 값과 황색도(yellowness)를 나타 내는 $b^{*}$ 값을 측정하였다. 이때 표준색은 $\mathrm{L}^{*}$ 값 이 $89.2, \mathrm{a}^{*}$ 값이 $0.921, \mathrm{~b}$ *값이 0.783 인 표준색 판을 사용하여 표준화한 다음 측정하였다.

\section{(5) Volatile basic nitrogen(VBN)}

高坂(1975)의 방법을 이용하여 세절육 $10 \mathrm{~g}$ 에 증류수 $90 \mathrm{ml}$ 를 가하여 $14,000 \mathrm{rpm}$ 으로 5 분간 균질한 후 균질액을 whatman No. 1로 여과하여 여과액 $1 \mathrm{ml}$ 를 conway unit 외실에 넣고 내실에 
는 $0.01 \mathrm{~N}$ 붕산용액 $1 \mathrm{ml}$ 와 지시약 $(0.066 \%$ methyl red $+0.066 \%$ bromocresol green)을 3방울 가한 다. 뚜껑과의 접착부위에 glycerine을 바르고 뚜 껑을 닫은 후 $50 \% \mathrm{~K}_{2} \mathrm{CO}_{3} 1 \mathrm{ml}$ 를 외실에 주입 후 즉시 밀폐시킨 다음 용기를 수평으로 교반 한 후 $37^{\circ} \mathrm{C}$ 에서 120 분간 배양 후 $0.02 \mathrm{~N} \mathrm{H}_{2} \mathrm{SO}_{4}$ 로 적정하여 다음과 같이 구하였다.

$\mathrm{VBN}(\mathrm{mg} \%)=(\mathrm{a}-\mathrm{b}) \times \mathrm{f} \times 0.02 \times 14.007 \times / \mathrm{S} \times 100 \times 100$

a: samlpe $\mathrm{ml}$, b: blank $\mathrm{ml}$,

S: sample wt, f: $0.02 \mathrm{~N} \mathrm{H}_{2} \mathrm{SO}_{4}$ factor

(6) Thiobarbituric acid reactive substances (TBARS)

Buege와 Aust(1978)의 방법에 의해 시료 $5 \mathrm{~g}$ 에 butylated hydroxyanisole(BHA) $50 \mu$ 와 증류 수 $15 \mathrm{ml}$ 을 첨가하여 균질화(IKA, T25 Basic Malaysia) 시킨 후 균질액 $1 \mathrm{ml}$ 을 시험관에 넣 고 여기에 $2 \mathrm{ml}$ thiobarbituric $\operatorname{acid}(\mathrm{TBA}) /$ trichloroacetic acid(TCA) 혼합용액을 넣어 완전히 혼합한 다음, $90^{\circ} \mathrm{C}$ 의 항온수조에서 15 분간 열 처리한 후 냉각시켜 $3,000 \mathrm{rpm}$ 에서 10 분간 원심 분리 시켰다. 원심 분리한 시료의 상층을 회수 하여 $531 \mathrm{~nm}$ 에서 흡광도를 측정하였다.

TBARS $=$ 흡광도 수치 $\times 5.88$

(7) 총세균

총균수(Total plate counts)는 시료 $10 \mathrm{~g}$ 을 $1 \%$ peptone수 $90 \mathrm{ml}$ 에 넣고 bagmixer로 균질시킨 다음 $1 \mathrm{ml}$ 를 채취하여 준비된 $9 \mathrm{ml}$ peptone 수에 넣어 희석한 후, 희석액을 미리 조제한 배지 (plate counter agar, Difco)에 평판 배양하여 32 ${ }^{\circ} \mathrm{C}$ 에서 2 일 배양한 후 나타나는 colony의 수를 계수하였다.

(8) 대장균

대장균(Escherichia coli)은 시료 $10 \mathrm{~g}$ 을 $1 \%$ peptone수 $90 \mathrm{ml}$ 에 넣고 bagmixer로 균질시킨 다음 $1 \mathrm{ml}$ 를 채취하여 준비된 $9 \mathrm{ml}$ peptone 수에 넣어 희석한 후, 희석액을 미리 조제한 배지 (MaCConkey agar, Difco)에 평판배양하여 $37^{\circ} \mathrm{C}$ 에서 1 일 배양한 후 나타나는 colony의 수를 계수하였다.

(9) 유산균

유산균(Lactobacilli spp.)은 시료 $10 \mathrm{~g}$ 을 $1 \%$ peptone 수 $90 \mathrm{ml}$ 에 넣고 bagmixer로 균질시킨 다음 $1 \mathrm{ml}$ 를 채취하여 준비된 $9 \mathrm{ml}$ peptone 수에 넣어 희석한 후, 희석액을 미리 조제한 배지 (Lactobacilli MRS agar, Difco)에 평판배양하여 $30^{\circ} \mathrm{C}$ 에서 2 일 배양한 후 나타나는 colony의 수 를 계수하였다.

\section{3. 통계처리}

이상의 실험에서 얻어진 결과는 $\mathrm{SAS}(1999)$ 프로그램을 이용하여 분산분석을 수행하였고, 처리 평균간의 비교를 위해 Duncan의 multiple range test로 $5 \%$ 수준에서 유의성을 검정하였다.

\section{III. 결과 및 고찰}

1. $\mathrm{pH}$

Table 2는 간장, 고추장 및 된장 양념을 이용 하여 발효한 돈육을 함기포장하여 저장기간에 따른 $\mathrm{pH}$ 변화를 나타내었다. 일반적으로 $\mathrm{pH}$ 는 발효 중에 약 $5 \%$ 정도가 감소하며, 60 일 정도 의 장기 저장 시 $0.1 \sim 0.2$ 가 증가하는데 이와 같 은 원인은 nonprotein nitrogen(NPN) 화합물의 출현 및 증가에 기인한다(Wardlow 등, 1973). 발효 돈육의 $\mathrm{pH}$ 는 4.65 6.26 범위였고, 저장 1 일에 간장 발효 돈육이 된장과 고추장 발효 돈 육에 비해 $\mathrm{pH}$ 가 낮았지만, 저장 14 일과 28 일에 간장 발효 돈육이 현저하게 높았다 $(\mathrm{P}<0.05)$. 
저장기간이 경과함에 따라 간장 발효 돈육은 14 일에 가장 높은 $\mathrm{pH}$ 를 보였으며, 고추장과 된 장 발효 돈육은 현저하게 감소하였다 $(\mathrm{P}<0.05)$. 최와 이(2002)는 10 일간 저장 중 저장 2 일 이후 고추장 양념육이 간장 양념육에 비해 $\mathrm{pH}$ 가 높 았으며, 간장 양념육을 10 일간 저장 중에 8 일 까지는 가열 전 $\mathrm{pH}$ 의 변화가 없었으나 10 일에 현저하게 낮았고, 고추장 양념육은 저장 6 일에 현저하게 높았다가 이후 현저하게 감소하였다 는 보고와 차이를 보였다. 또한 Jin 등(2005)은 10 일간 숙성하여 함기포장한 된장 발효 돈육은 고추장 발효 돈육에 비해 높은 $\mathrm{pH}$ 를 나타내었 고, 저장기간이 경과함에 따라 저장 1 주에 비 해 2 주에 낮아졌다가 3 주에 다시 상승하였다는 보고하였고, Kim 등(2002)도 여러 가지 포장방 법에 의하여 포장된 양념육의 $\mathrm{pH}$ 가 저장기간 에 따른 차이가 없다고 보고한 결과들과 차이 를 보였다. 이와 같은 차이는 양념육의 발효조 건과 양념액의 배합비 차이 등에 의한 것으로 판단된다.

\section{2. 보수력}

Table 3은 간장, 고추장 및 된장 양념을 이용 하여 발효한 돈육을 함기포장하여 저장기간에 따른 보수성의 변화를 나타내었다. 보수성은 저장 1 일과 28 일에 간장 발효 돈육이 고추장과
Table 2. $\mathrm{pH}$ of aerobic packed fermented pork during stora?

\begin{tabular}{ccr}
\hline Treatments $^{1)}$ & 1 & Storage( \\
\cline { 2 - 3 } & $5.46 \pm 0.03^{\mathrm{Cb}}$ & $5.57 \pm($ \\
\hline T1 & $6.13 \pm 0.01^{\mathrm{Ba}}$ & $5.09 \pm($ \\
$\mathrm{T} 2$ & $6.26 \pm 0.04^{\mathrm{Aa}}$ & $4.97 \pm($ \\
$\mathrm{T} 3$ & \\
\hline
\end{tabular}

$\overline{A, B, C}$ Means with different superscripts in the same column are significar ${ }^{a, b, c}$ Means with different superscripts in the same row are significantly 1) Treatments are the same as in Table 1.

된장 발효 돈육에 비해 현저하게 높았고 $(\mathrm{P}<$ $0.05), 14$ 일에는 차이를 보이지 않았다. 저장기 간이 경과함에 따라 간장 발효 돈육의 보수력 은 약간 상승하였고, 된장 발효 돈육은 현저하 게 감소하였다. 저장기간 경과에 따른 간장 발효 돈육의 보수력 상승은 근육 조직의 팽 윤과 간장 내 염의 침투에 기인하는 듯하며, Wierbicki 등(1957)은 소금이 육의 보수력을 높 인다는 보고는 본 연구 결과를 뒷받침 하고 있 다. 또한 Jin 등(2005)은 10 일간 숙성하여 함기 포장한 된장 발효 돈육과 고추장 발효 돈육의 보수성은 차이가 없었다는 보고는 본 시험 결 과와 일치하였지만, 저장기간이 경과함에 약간 상승하였다는 결과와는 차이를 보였다. 식육을 저장할 경우, 단백질 변성에 의해 보수력이 저 하하게 되는데 그 결과 다즙성 및 물성 측면에 서 소비자들의 기호도를 저하시키는 주요 원인

Table 3. Water holding capacity of aerobic packed fermented pork during storage at $1 \pm 1^{\circ} \mathrm{C}$

\begin{tabular}{cccc}
\hline & \multicolumn{3}{c}{ (Unit : \%) } \\
\cline { 2 - 4 } Treatments $^{1)}$ & 1 & 14 & 28 \\
\hline \hline $\mathrm{T} 1$ & $79.76 \pm 4.13^{\mathrm{A}}$ & $78.55 \pm 14.10$ & $85.87 \pm 4.61^{\mathrm{A}}$ \\
$\mathrm{T} 2$ & $73.60 \pm 1.94^{\mathrm{B}}$ & $80.45 \pm 13.47$ & $64.45 \pm 5.49^{\mathrm{B}}$ \\
$\mathrm{T} 3$ & $71.40 \pm 1.14^{\mathrm{Ba}}$ & $68.86 \pm 2.42^{\mathrm{a}}$ & $62.93 \pm 3.11^{\mathrm{Bb}}$ \\
\hline
\end{tabular}

\footnotetext{
A,B Means with different superscripts in the same column are significantly different $(\mathrm{P}<0.05)$.

a,b Means with different superscripts in the same row are significantly different $(\mathrm{P}<0.05)$.

1) Treatments are the same as in Table 1.
} 
이 되며, 동시에 미생물의 오염을 촉진시킬 수 있다(Kauffman 등, 1986). 본 연구결과 저장 중 간장, 고추장 및 된장 발효 돈육은 일정한 보 수력을 유지하게 되어 품질유지에 큰 영향을 미치지 않을 것으로 사료된다.

\section{3. 전단가}

Table 4는 간장, 고추장 및 된장 양념을 이 용하여 발효한 돈육을 함기포장하여 저장기간 에 따른 전단가의 변화를 나타내었다. 전단가 는 된장 발효 돈육이 간장과 고추장 발효 돈육 에 비해 낮은 전단가를 나타내었고, 저장기간 이 경과함에 된장 발효 돈육은 현저하게 감소 하였다 $(\mathrm{P}<0.05)$. Jin 등 $(2005)$ 은 10 일간 숙성하 여 함기포장한 된장 발효 돈육이 저장 1 주에 고추장 발효 돈육에 비해 전단가는 높았지만,
후 양념 소스의 조성과 발효육 상호간에 미치 는 요인들에 대한 더 많은 연구가 필요하다고 판단된다.

\section{4. 발효 돈육의 표면 및 심부 육색}

Table 5는 간장, 고추장 및 된장 양념을 이용 하여 발효한 돈육을 함기포장하여 저장 1 일째 표면 및 심부 육색을 나타내었다. 저장 28 일까 지 실험하였으나 처리 간에 비슷한 결과를 보 였다. 육색의 변화는 산소의 유무 및 양, 저장 온도, 육 조직 내의 효소활동, 미생물의 오염 도, $\mathrm{pH}$, 포장방법, 빛 압력 등에 따라서 달라진 다(Cornforth, 1994). 표면 육색의 $\mathrm{L}^{*}$ 값은 된장 발효 돈육이 간장과 고추장 발효 돈육에 비해 높았지만, $\mathrm{a}^{*}$ 와 $\mathrm{b}^{*}$ 값은 고추장 발효 돈육이 간 장과 된장 발효 돈육에 비해 현저하게 높았다

Table 4. Shear force of aerobic packed fermented pork during storage at $1 \pm 1{ }^{\circ} \mathrm{C}$

(Unit : $\mathrm{g} / \mathrm{cm} 2$ )

\begin{tabular}{cccc}
\hline & \multicolumn{3}{c}{ Storage(days) } \\
\cline { 2 - 4 } Treatments $^{1)}$ & 1 & 14 & 28 \\
\hline \hline T1 & $4,240 \pm 122^{\mathrm{Aa}}$ & $3,650 \pm 87^{\mathrm{Ab}}$ & $3,764 \pm 97^{\mathrm{Ab}}$ \\
T2 & $3,033 \pm 108^{\mathrm{B}}$ & $3,011 \pm 213^{\mathrm{B}}$ & $3,063 \pm 87^{\mathrm{B}}$ \\
T3 & $3,002 \pm 19^{\mathrm{Ba}}$ & $2,799 \pm 35^{\mathrm{Bb}}$ & $2,577 \pm 122^{\mathrm{Cc}}$ \\
\hline
\end{tabular}

\footnotetext{
A,B,C Means with different superscripts in the same column are significantly $\operatorname{different}(\mathrm{P}<0.05)$.

a,b,c Means with different superscripts in the same column are significantly $\operatorname{different}(\mathrm{P}<0.05)$.

1) Treatments are the same as in Table 1.

저장 2주와 3주에 현저히 낮았다는 보고와 본 연구결과와 유사한 경향이었다. 연도의 향상은 고기의 사후 숙성과 관련되며, 숙성기간 동안 고기의 연화기전은 아직까지 명확하게 밝혀지 지는 않았으나, 일반적으로 사후 $\mathrm{pH}$ 와 온도가 연도에 영향을 미치며(Yu와 Lee, 1986), 주로 근육 내 효소들에 의한 근원섬유단백질 등의 분해로 고기가 연화된다고 하였다(Yates 등, 1983). 본 연구결과 $\mathrm{pH}$, 보수성 및 전단력(Table 2, 3 및 4) 상호간의 해석이 불분명하였기에 향

$(\mathrm{P}<0.05)$. 또한 심부 육색도 표면 육색과 비슷 한 경향을 나타내었다. Jin 등(2005)은 된장 발 효 돈육이 고추장 발효 돈육에 비해 $\mathrm{L}^{*}$ 값은 높았고, $\mathrm{a}^{*}$ 와 $\mathrm{b}^{*}$ 값은 현저하게 낮았다는 보고 와 유사하였다. 양념육에 있어서의 문제점인 육색의 큰 변화, 특히 적색도의 저하 현상을 고추장 양념을 이용하여 발효시킴으로서 억제 하여 소비자들이 좋아하는 바람직한 붉은 색을 유지할 수 있어 양념돈육의 품질 유지에 기여 할 것으로 판단된다.
} 


\section{VBN}

Table 6은 간장, 고추장 및 된장 양념을 이용 하여 발효한 돈육을 함기포장하여 저장기간에 따른 휘발성염기태질소화합물 $(\mathrm{VBN})$ 의 변화를 나타내었다. Dierick 등(1974)은 숙성 시 비단백 태 질소화합물이 증가하여 독특한 맛과 향을 내게 된다고 하였으며, Lefebvre 등(1994)은 휘 발성염기태질소화합물은 육류에 많이 오염되어 있어 Pseudomonas spp. 등과 같은 Gram negative bacteria에 의해 요소와 아미노산이 분해됨 으로써 형성된다고 하였다. 저장 1 일과 14 일에 된장 발효 돈육이 고추장 발효 돈육에 비해 낮 았지만, 저장 28 일에는 간장 발효 돈육이 고추 장과 된장 발효 돈육에 비해 현저하게 낮았다 $(\mathrm{P}<0.05)$. 저장기간이 경과함에 따라 간장, 고 추장 및 된장 발효 돈육 모두 증가하였다. Choi 와 $\mathrm{Lee}(2002)$ 는 양념육을 $5^{\circ} \mathrm{C}$ 에 저장했을 때 고 추장 양념육이 저장 6 일까지 간장 발효 돈육에 비해 약간 낮았으나, 저장 8 일과 10 일에는 높 았다는 보고와 차이를 보였지만 저장기기간 경 과함에 따라 $\mathrm{VBN}$ 이 증가한 것은 유사하였다. Jin 등(2005)은 10 일간 숙성하여 함기포장한 된 장 발효 돈육이 저장 1 주에 고추장 발효 돈육 에 비해 높았지만, 2주와 3주에는 현저하게 낮 았다는 보고와 유사한 경향이었다. 또한 저장
Table 5. Surface and inner color(Hunter $\left.L^{*}, a^{*}, b^{*}\right)$ of aero 1 day storage at $1 \pm 1^{\circ} \mathrm{C}$

\begin{tabular}{|c|c|c|c|}
\hline & & & Treatmer \\
\hline & & $\mathrm{T} 1$ & $\mathrm{~T} 2$ \\
\hline \multirow{3}{*}{ Surface color } & $\mathrm{L}^{*}$ & $38.49 \pm 1.82^{\mathrm{C}}$ & $43.42 \pm 1$ \\
\hline & $a^{*}$ & $4.32 \pm 0.88^{\mathrm{B}}$ & $10.27 \pm 1$ \\
\hline & $b^{*}$ & $9.81 \pm 0.49^{\mathrm{B}}$ & $24.66 \pm 1$ \\
\hline \multirow{3}{*}{ Inner color } & $\mathrm{L}^{*}$ & $42.08 \pm 2.14^{\mathrm{C}}$ & $48.61 \pm($ \\
\hline & $a^{*}$ & $6.51 \pm 0.61^{\mathrm{A}}$ & $5.90 \pm C$ \\
\hline & $b^{*}$ & $3.75 \pm 0.33^{\mathrm{B}}$ & $8.02 \pm 2$ \\
\hline
\end{tabular}

$\overline{A, B, C}$ Means with different superscripts in the same row are significantly 1) Treatments are the same as in Table 1.

기간이 경과함에 따라 $\mathrm{VBN}$ 은 증가한다는 $\mathrm{Jin}$ 등(2005)의 결과와 본 연구결과와 일치하였다. 高坂(1975)은 생육의 $\mathrm{VBN}$ 값이 $30 \mathrm{mg} \%$ 이상이 되면 부패한 수준으로 판정하였으나 육제품은 그 이상이 되어도 부패하지 않은 경우가 있다 고 하였다. 본 실험에서는 저장 1 일의 $\mathrm{VBN}$ 이 $51 \mathrm{mg} \%$ 이상을 나타내었으며 저장 28 일에 $78.19 \sim 92.75 \mathrm{mg} \%$ 로 상당히 높았는데 이는 육 자체에서 기인되는 것보다 소스 제조 시 이용 되었던 간장, 고추장 및 된장 등의 발효에 기 인하는 것으로 판단되고, 또한 양념육은 함기 포장 형태로 제조되었기 때문에 저장 중 미약 하나마 호기성 미생물의 번식에 의한 단백질 분해가 이루어진 것으로 판단된다.

Table 6. VBN of aerobic packed fermented pork during storage at $1 \pm 1^{\circ} \mathrm{C}$

(Unit : mg\%)

\begin{tabular}{cccc}
\hline Treatments $^{1)}$ & \multicolumn{3}{c}{ Storage(days) } \\
\cline { 2 - 4 } & 1 & 14 & 28 \\
\hline \hline $\mathrm{T} 1$ & $57.61 \pm 5.30^{\mathrm{ABb}}$ & $69.31 \pm 5.46^{\mathrm{Aa}}$ & $78.19 \pm 5.41^{\mathrm{Ba}}$ \\
$\mathrm{T} 2$ & $67.08 \pm 5.28^{\mathrm{Ab}}$ & $69.33 \pm 2.08^{\mathrm{Ab}}$ & $87.53 \pm 0.45^{\mathrm{Aa}}$ \\
$\mathrm{T} 3$ & $51.83 \pm 5.28^{\mathrm{Bb}}$ & $56.98 \pm 5.45^{\mathrm{Bb}}$ & $92.75 \pm 3.85^{\mathrm{Aa}}$ \\
\hline
\end{tabular}

\footnotetext{
$\mathrm{A}, \mathrm{B}$ Means with different superscripts in the same column are significantly $\operatorname{different}(\mathrm{P}<0.05)$.

a,b Means with different superscripts in the same row are significantly $\operatorname{different}(\mathrm{P}<0.05)$.

1) Treatments are the same as in Table 1.
} 


\section{TBARS}

Table 7은 간장, 고추장 및 된장 양념을 이용
는 양념의 색, 지방 또는 당류 등에 의하여 비색법으로 측정 시 수치가 높아진 것으로 추측되었다.

Table 7. TBARS of aerobic packed fermented pork during storage at $1 \pm 1{ }^{\circ} \mathrm{C}$

(Unit : MAmg/kg)

\begin{tabular}{cccc}
\hline & \multicolumn{3}{c}{ Storage(days) } \\
\cline { 2 - 4 } Treatments $^{1)}$ & 1 & 14 & 28 \\
\hline \hline T1 & $0.55 \pm 0.10^{\mathrm{b}}$ & $0.62 \pm 0.01^{\mathrm{Bb}}$ & $0.82 \pm 0.02^{\mathrm{Ba}}$ \\
$\mathrm{T} 2$ & $0.72 \pm 0.35$ & $1.10 \pm 0.02^{\mathrm{A}}$ & $1.12 \pm 0.03^{\mathrm{A}}$ \\
T3 & $0.37 \pm 0.01$ & $0.45 \pm 0.12^{\mathrm{C}}$ & $0.45 \pm 0.02^{\mathrm{C}}$ \\
\hline
\end{tabular}

A,B,C Means with different superscripts in the same column are significantly $\operatorname{different}(\mathrm{P}<0.05)$.

${ }^{a, b}$ Means with different superscripts in the same row are significantly $\operatorname{different}(\mathrm{P}<0.05)$.

1) Treatments are the same as in Table 1.

하여 발효한 돈육을 함기포장하여 저장기간에 따른 TBARS의 변화를 나타내었다. 지방산화가 진행되면 malonaldehyde, acetal 화합물 등이 증 가하는데 이에 2-thiobarbituric acid를 반응시켜, 발색된 색의 정도로부터 이들의 유리화합물, 즉 산화의 촉진 정도를 측정하고 있다(Melton, 1983). TBARS는 된장 발효 돈육이 간장과 고 추장 발효 돈육에 비해 현저하게 낮았고 $(\mathrm{P}<$ $0.05)$, 저장기간이 경과함에 따라 발효 돈육 모두 TBARS는 증가하였다. Choi와 Lee (2002) 는 양념육을 $5^{\circ} \mathrm{C}$ 에 저장했을 때 $\mathrm{TBARS}$ 는 고 추장 양념육이 간장 발효 돈육에 비해 약간 낮았다는 보고와 차이를 보였으며, 저장기간 이 경과함에 따라 증가하였다는 보고와 일치 하였다. Jin 등(2005)은 10 일간 숙성하여 함기 포장한 된장 발효 돈육이 고추장 발효 돈육 에 비해 높았다는 보고와 차이를 보였는데, 이는 양념의 원료나 배합비 차이에 기인되는 것으로 사료된다. 저장기간이 경과함에 따라 지질의 산화도가 증가한다는 보고(Witte 등, 1970; Youn 등, 2004)와 일치하였다. 본 연구 에서는 TBARS가 0.37 1.12 MAmg/kg 범위로 상당히 높았다. 이는 양념육에 포함되어 있

\section{7. 미생물}

Table 8 10은 간장, 고추장 및 된장 양념을 이용하여 발효한 돈육을 함기포장하여 저장기 간에 따른 미생물의 변화를 나타내었다. Newton 과 $\operatorname{Rigg(1979)}$ 에 따르면 냉장육의 유통기한은 초기 미생물 수, 저장기간, 저장온도 및 포장방 법 등에 따라 결정된다고 하였다. Table 8 은 총 균수를 나타낸 결과로서 총균수는 저장 1 일에 간장 발효 돈육이 $4.59 \log _{10} \mathrm{CFU} / \mathrm{g}$ 으로 고추장 과 된장 발효 돈육의 5.22 와 $5.17 \log _{10} \mathrm{CFU} / \mathrm{g}$ 에 비해 낮았지만, 저장 14 일과 28 일에 고추장 발 효 돈육이 5.00 과 $5.05 \log _{10} \mathrm{CFU} / \mathrm{g}$ 으로 간장 및 된장 발효 돈육의 5.15 와 $6.36 \log _{10} \mathrm{CFU} / \mathrm{g}$ 및 5.17 과 $6.58 \log _{10} \mathrm{CFU} / \mathrm{g}$ 에 비해 현저하게 낮았 다 $(\mathrm{P}<0.05)$. 저장기간이 경과함에 따라 고추장 발효 돈육은 저장 1 일에 높았지만, 간장과 된 장 발효 돈육은 저장 28 일에 가장 높았다 $(\mathrm{P}<$ 0.05). Choi와 Lee(2002)는 간장 양념육이 고추 장 양념육에 비해 낮은 총균수를 나타내었다고 하였으며, Jin 등(2005)은 10 일간 숙성하여 함기 포장한 고추장 발효 돈육이 된장 발효 돈육에 비해 낮은 총균수를 나타내었고, 된장과 고추 
Table 8. Total plate counts of aerobic packed fermented pork during storage at $1 \pm 1{ }^{\circ} \mathrm{C}$

(Unit : $\log _{10} \mathrm{CFU} / \mathrm{g}$ )

\begin{tabular}{cccc}
\hline & \multicolumn{3}{c}{ Storage(days) } \\
\cline { 2 - 4 } Treatments $^{1)}$ & 1 & 14 & 28 \\
\hline \hline $\mathrm{T} 1$ & $4.59 \pm 0.07^{\mathrm{Bc}}$ & $5.15 \pm 0.09^{\mathrm{Ab}}$ & $6.36 \pm 0.09^{\mathrm{Ba}}$ \\
$\mathrm{T} 2$ & $5.22 \pm 0.03^{\mathrm{Aa}}$ & $5.00 \pm 0.01^{\mathrm{Bc}}$ & $5.05 \pm 0.01^{\mathrm{Cb}}$ \\
$\mathrm{T} 3$ & $5.17 \pm 0.01^{\mathrm{Ab}}$ & $5.17 \pm 0.07^{\mathrm{Ab}}$ & $6.58 \pm 0.00^{\mathrm{Aa}}$ \\
\hline
\end{tabular}

$\overline{\mathrm{A}, \mathrm{B}, \mathrm{C}}$ Means with different superscripts in the same column are significantly $\operatorname{different}(\mathrm{P}<0.05)$.

a,b,c Means with different superscripts in the same row are significantly $\operatorname{different}(\mathrm{P}<0.05)$.

1) Treatments are the same as in Table 1.

Table 9. Escherichia coli of aerobic packed fermented pork during storage at $1 \pm 1{ }^{\circ} \mathrm{C}$

(Unit : $\log _{10} \mathrm{CFU} / \mathrm{g}$ )

\begin{tabular}{cccc}
\hline \multirow{2}{*}{ Treatments $^{1)}$} & \multicolumn{3}{c}{ Storage(days) } \\
\cline { 2 - 4 } & 1 & 14 & 28 \\
\hline \hline T1 & $3.43 \pm 0.06^{\mathrm{Ba}}$ & $3.12 \pm 0.07^{\mathrm{b}}$ & $2.45 \pm 0.14^{\mathrm{c}}$ \\
$\mathrm{T} 2$ & $3.60 \pm 0.03^{\mathrm{A}}$ & $\mathrm{NG}$ & $\mathrm{NG}$ \\
$\mathrm{T} 3$ & $3.41 \pm 0.08^{\mathrm{B}}$ & $\mathrm{NG}$ & $\mathrm{NG}$ \\
\hline
\end{tabular}

$\mathrm{A}, \mathrm{B}$ Means with different superscripts in the same column are significantly $\operatorname{different}(\mathrm{P}<0.05)$.

${ }^{a, b, c}$ Means with different superscripts in the same row are significantly $\operatorname{different}(\mathrm{P}<0.05)$.

1) Treatments are the same as in Table 1.

NG : Indicates no growth on plates.

장 발효 돈육은 저장 1 주에서 3 주까지 총균수

Table 10. Lactobacilli spp. of aerobic packed fermented pork

는 증가한다는 보고와 유사하였다. 또한 Choi

와 Lee(2002)는 간장 양념육의 총균수는 저장기

간이 경과함에 따라 점차 증가하였다는 보고와

일치하였지만 고추장 양념육의 증가와는 다소 차이를 보였다. Ingram과 Dainty(1971)는 총균수

가 $7 \log _{10} \mathrm{CFU} / \mathrm{cm}^{2}$ 이상이 되면 육에서 이취가 발생하고 $8 \log _{10} \mathrm{CFU} / \mathrm{cm}^{2}$ 수준이 되면 점액이 형성된다고 하였다. 본 연구에서의 발효 돈육 은 이취나 제품의 관능상의 문제는 없는 것으 로 판단되었다.

Table 9는 대장균수의 변화를 나타낸 결과로 서 저장 1 일에 간장과 된장 발효 돈육이 고추 장 발효 돈육에 비해 현저하게 낮은 대장균수 를 나타내었고 $(\mathrm{P}<0.05)$, 저장 14 일과 28일에는 고추장과 된장 발효 돈육은 대장균 성장을 나

\begin{tabular}{ccc}
\hline & & Storage(di \\
\cline { 2 - 3 } Treatments $^{1)}$ & 1 & 14 \\
\hline \hline T1 & $5.00 \pm 0.13^{\mathrm{Ac}}$ & $5.52 \pm 0$. \\
T2 & $4.66 \pm 0.02^{\mathrm{Ba}}$ & $4.63 \pm 0$. \\
T3 & $4.88 \pm 0.04^{\mathrm{Ab}}$ & $4.61 \pm 0$. \\
\hline
\end{tabular}

\footnotetext{
$\overline{\mathrm{A}, \mathrm{B}}$ Means with different superscripts in the same column are significantl: a,b,c Means with different superscripts in the same row are significantly $d$

1) Treatments are the same as in Table 1.
}

타내지 않았다. 저장기간이 경과함에 따라 간 장 발효 돈육의 대장균수는 현저하게 감소하였 다 $(\mathrm{P}<0.05)$. Jin 등 $(2005)$ 은 10 일간 숙성하여 함 기포장한 된장과 고추장 발효 돈육사이 저장 1 주내에 대장균 수는 차이가 없었고, 저장 2 주 
와 3 주에 대장균 성장을 나타내지 않았다는 보 고와 유사하였다. Jin 등(2004)은 E. coil 배양액 을 각각 $1.5 \times 10^{3}$ 씩 인위적으로 접종하여 5 가 지의 전통양념에 침지하여 발효시킨 돈육의 발 효기간 중 미생물 증식에서 접종 3 일까지 된장 과 고추장 발효 돈육의 대장균 수는 $10^{3} \sim 10^{4}$ $\mathrm{CFU} / \mathrm{cm}^{2}$ 까지 증가한 후 발효 28 일에는 접종 수준 이하로 낮아졌다는 보고와 유사하였다. 이는 발효식품 중에 서식하고 있는 발효미생물 의 영향으로 양념의 주종균인 유산균이 배출하 는 항생물질, 이산화탄소, 유기산 등에 의해 미 생물 성장이 억제되었기 때문으로 판단된다 $(\mathrm{Fu}$ 등, 1992).

Table 10은 유산균 수를 나타내었다. 유산균 수는 고추장 발효 돈육이 간장과 된장 발효 돈 육에 비해 현저하게 낮은 수를 나타내었다 $(\mathrm{P}<$ 0.05). 저장기간이 경과함에 따라 간장과 된장 발효 돈육은 저장 28 일에 높은 유산균 수를 나 타내었지만 $(\mathrm{P}<0.05)$, 고추장 발효 돈육은 저장 14일에 높았다. Choi와 Lee(2002)는 전체적으로 고추장 양념육이 된장 양념육에 비해 유산균 수는 낮았고, 저장기간이 경과함에 따라 유산 균수가 증가한다는 보고와 유사하였다. 간장 발효 돈육의 유산균 수의 증가는 간장 내 염의 침투에 기인하는 듯하며, 발효 육제품에서 있 어서 소금은 염용성 단백질을 추출하여 결착력 을 높이고 향미를 증진시키며, 염지육을 발효 시킬 때 이미 오염된 미생물의 성장을 억제시 켜, 상대적으로 내염성의 젖산균이 잘 자라도 록 도와주는 역할을 한다(Pederson, 1979)는 보 고는 본 연구결과를 뒷받침하고 있다. Jin 등 (2005)은 10 일간 숙성하여 함기포장한 고추장 발효 돈육이 된장 발효 돈육에 비해 유산균 수 가 낮았고, 저장기간이 경과함에 따라 고추장 발효 돈육은 저장 14 일, 된장 발효 돈육은 28 일에 가장 높은 유산균 수를 나타내었다는 보 고와 일치하였다.

\section{IV. 요 약}

이 연구는 간장, 고추장 및 된장 양념을 이 용한 발효 돈육의 품질 특성에 관한 것으로 돼 지 뒷다리를 채취하여 $7 \times 10 \times 2 \mathrm{~cm}$ 크기로 자 른 후 육을 동일한 비율의 소스(간장소스 $\mathrm{T} 1$, 고추장소스 $\mathrm{T} 2$, 된장소스 $\mathrm{T} 3$ )에 침지하여 $1 \pm$ $1^{\circ} \mathrm{C}$ 에서 10 일간 발효숙성한 후 함기포장하여 1 $\pm 1^{\circ} \mathrm{C}$ 에서 1,14 및 28 일 동안 저장하면서 품질 측정한 결과는 다음과 같다. $\mathrm{pH}$ 는 $\mathrm{T} 1$ 이 저장 1 일에 $\mathrm{T} 2$ 와 $\mathrm{T} 3$ 에 비해 낮았지만, 저장 14 일과 28 일에 현저하게 높았다 $(\mathrm{P}<0.05)$. 보수성은 $\mathrm{T} 1$ 이 저장 1 일과 28 일에 $\mathrm{T} 2$ 와 $\mathrm{T} 3$ 에 비해 높았다. 전단가는 $\mathrm{T} 3$ 가 $\mathrm{T} 1$ 과 $\mathrm{T} 2$ 에 비해 낮았다. 표면 육색의 $\mathrm{L}^{*}$ 값은 $\mathrm{T} 3$ 가 $\mathrm{T} 1$ 과 $\mathrm{T} 2$ 에 비해 높았지 만, $\mathrm{a}^{*}$ 와 $\mathrm{b}$ * 값은 $\mathrm{T} 2$ 가 $\mathrm{T} 1$ 과 $\mathrm{T} 3$ 에 비해 현저하 게 높았다 $(\mathrm{P}<0.05) . \mathrm{VBN}$ 은 저장 1 일과 14 일에 $\mathrm{T} 3$ 가 $\mathrm{T} 2$ 에 비해 낮았지만, 저장 28 일에는 $\mathrm{T} 1$ 이 $\mathrm{T} 2$ 와 $\mathrm{T} 3$ 에 비해 현저하게 낮았다 $(\mathrm{P}<0.05)$. $\mathrm{TBARS}$ 는 저장 14 일과 28 일에 $\mathrm{T} 3$ 가 $\mathrm{T} 1$ 과 $\mathrm{T} 2$ 에 비해 현저하게 낮았다 $(\mathrm{P}<0.05)$. 총균수는 저장 1 일에 $\mathrm{T} 1$ 이 $\mathrm{T} 2$ 와 $\mathrm{T} 3$ 에 비해 낮았지만, 저장 14 일과 28 일에는 $\mathrm{T} 2$ 가 $\mathrm{T} 1$ 과 $\mathrm{T} 3$ 에 비해 현저하게 낮았다 $(\mathrm{P}<0.05)$. 대장균 수는 저장 1 일에 $\mathrm{T} 1$ 과 $\mathrm{T} 3$ 가 $\mathrm{T} 2$ 에 비해 현저하게 낮았고 $(\mathrm{P}<0.05)$, 저 장 14 일과 28 일에는 $\mathrm{T} 2$ 와 $\mathrm{T} 3$ 는 대장균 성장을 나타내지 않았다. 유산균 수는 T2가 $\mathrm{T} 1$ 과 $\mathrm{T} 3$ 에 비해 낮았다. 이상에서, 고추장 발효 돈육인 $\mathrm{T} 2$ 는 양념육 고유의 색을 나타내면서 미생물 성 장을 지연시켰다.

$$
\text { V. 사 사 }
$$

본 연구는 2003년도 한국학술진흥재단(KRF2003-002-F00028)의 지원에 의하여 이루어진 것 으로 연구비 지원에 감사를 표합니다.

\section{VI. 인 용 문 헌}


1. Buege, J. A. and Aust, S. D. 1978. Microsomal lipid peroxidation. Methods Enzymol. 52:302-309.

2. Cornforth, D. P. 1994. Color: Its basis and importance. In Quality Attributes and Their Measurement in Meat, Poultry and Fish Product, A. M. Pearson and T. R. Dutson(Ed), Blackie Academic \& Professional, London, p.39.

3. Choi, W. S. and Lee, K. T. 2002. Quality changes and shelf-life of seasoned with soy sauce or Kochujang during chilled storage. Kor. J. Food Sci. Ani. Resour. 22(3):240-246.

4. Crepo, F. L., Millian, R. and Serrani Moreno, A. 1978. Chemical changes during ripening of spanish dry sausage(Salchivos) III. Changes in water-soluble $\mathrm{N}$ compounds. Archivos de Zootecnia. 27:105-112.

5. Dierick, E. A., Vandekerckhove, P. and Demeyer, D. 1974. Changes in nonprotein nitrogen compounds during dry sausage ripening. J. Food Sci. 39:301-308.

6. Fu, A. H., Molins, R. A. and Sebranek, J. G. 1992. Storage quality characteristics of beef rib eye steaks packaged in modified atmospheres. J. Food Sci. 57:283-287.

7. Gill, C. O. and Badoni, M. 2002. Microbiological and organoleptic qualities of vacuum-packaged ground beef prepared from pasteurized manufacturing beef. Inter. J. Food Microbiol. 74:111118.

8. Ingram, M. and Dainty, R. H. 1971. Changes caused by microbes in spoilaged of meats., J.
Appl. Bact. 34(1):21-39.

9. Jin, S. K., Kim, C. W., Lee, S. W., Song, Y. M., Kim, I. S., Park, S. K., Hah, K. H. and Bae, D. S. 2004. Effects of Korean traditional seasonings on growth of pathogenic germ in fermented pork. Kor. J. Food Sci. Ani. Resour. 24(2):103-107.

10. Jin, S. K., Kim, I. S., Hah, K. H., Hur, S. J., Lyou, H. J., Park, K. H. and Bae, D. S. 2005. J. Anim. Sci. \& Technol.(Kor). 47(1):73-82.

11. Kauffman, R. G., Eikelenboom, G., Vander Wal, P. G., Engel, B. and Zaar, M. 1986. A comparison of methods to estimate water holding capacity in post-rigor porcine muscle. Meat Sci. 18:307-322.

12. KFDA. 2002. Official Book for Food.

13. Kim, C. J., Jeong, J. Y., Lee, E. S. and Song, H. H. 2002. Studies on improvement of quality and shelf-life of traditional marinated beef(Galbi) as affected by packaging method during storage at $-1^{\circ} \mathrm{C}$. Korea J. Food Sci. Technol. 34:792-798.

14. Lawrie, R. A. 1985. Meat Sci(4th ed). p. Oxford: Pergamon Press.

15. Lefebvre, N., Thibault, C., Charbonneau, R. and Piette, J. P. G. 1994. Improvement of shelf-life and wholesomeness of ground beef by irradiation. Meat Sci. 32:371-383.

16. Melton, S. L. 1983. Methodology following lipid oxidation in muscle food. Food Technol. 37:105108.

17. MFA. 2001. Statistical yearbook of agricultural and forestry industries. 
18. Moon, J. H., Ryu, H. S. and Lee, K. H. 1991. Effect of garlic on the digestion of beef protein during storage. J. Korean Soc. Food Sci. Nutr. 20:447-454.

19. Newton, K. G. and Rigg, W. J. 1979. The effect of film permeability on the storage life and microbiology of vacuum-packed meat. J. Apple. Bact. 47:433-441.

20. Pederson, C. S. 1979. Fermented sausage. In Microbiology of Food Fermentation, 2nd ed., p.210. AVI.

21. SAS. 1999. SAS/STAT Software for PC. Release 6.11, SAS institute, Cary, NC, U.S.A.

22. Wardlow, F. B., Skelley, G. C., Johnson, M. G. and Acton, J. C. 1973. Changes in meat components during fermentation, heat processing and drying of summer sausage. J. Food Sci. 38:1228-1234.

23. Whitaker, J. R. 1978. Biochemical changes occuring during the fermentation of high protein foods. Food Technol. 32:175-181.

24. Wierbicki, E., Kunkel, L. E. and Deatherage, F. E. 1957. Changes in the water holding capacity and cationic shifts during heating and freezing and thawing of meat as revealed by a simple centrifugal method for measuring shrinkage. Food Technol. 11:69-73.

25. Witte, V. C., Krause, G. F. and Bailey, M. E. 1970. New extraction method for determining 2-thiobarbituric acid values of pork and beef during storage. J. Food Sci. 35:582-585.

26. Yates, L. D., Dutson, T. R., Caldwell, J. and Carpenter, Z. L. 1983. Effect of temperature and $\mathrm{pH}$ on the post-mortem degradation of myofibrillar proteins. Meat Sci. 9:157-162.

27. Youn, S. K., Choi, J. S., Park, S. M. and Ahn, D. H. 2004. Studies on the improvement of shelf-life and quality of vacuum-packaged seasoned pork meat by added chitosan during storage. J. Anim. Sci. \& Technol.(Kor). 46(6):1023-1030.

28. Yu, L. P. and Lee, Y. B. 1986. Effects of postmortem $\mathrm{pH}$ and temperature on bovine muscle structure and meat tenderness. J. Food Sci. 51: 774-780.

29. 농림부. 2004. 식육의 부위별. 등급별 및 종류별 구분방법. 농림부 고시 제2004-67호.
30. 高坂和久. 1975. 肉製品の鮮度保持と 測定. 食 品工業. 18(4):105-111.

(접수일자 : 2005. 4. 15. / 채택일자 : 2005. 7. 25.) 